\title{
Very Poor
}

National Cancer Institute

\section{Source}

National Cancer Institute. Very Poor. NCI Thesaurus. Code C104315.

Of especially low value or worth. 